\title{
The Implemention of Total Productive Maintenance in Malaysia Automotive Industry
}

\author{
Nurul Fadly Habidin ${ }^{1}$, Suzaituladwini Hashim ${ }^{2}$, Nursyazwani Mohd Fuzi ${ }^{2}$, Mad Ithnin Salleh ${ }^{1}$, Wan Salmuni Wan \\ Mustaffa $^{1} \&$ Norlaile Salleh Hudin ${ }^{1}$ \\ ${ }^{1}$ Department of Business Management and Entrepreneurship, Faculty of Management and Economics, Universiti \\ Pendidikan Sultan Idris, Tanjung Malim, Malaysia \\ ${ }^{2}$ Department of Accounting and Finance, Faculty of Management and Economics, Universiti Pendidikan Sultan Idris, \\ Tanjung Malim, Malaysia \\ Correspondence: Nurul Fadly Habidin, Department of Business Management and Entrepreneurship, Faculty of \\ Management and Economics, Universiti Pendidikan Sultan Idris, 35900 Tanjung Malim, Perak, Malaysia. E-mail: \\ fadly@fpe.upsi.edu.my
}

Received: October 10, 2019

Accepted: November 5, 2019

Online Published: December 23, 2019

doi:10.5430/rwe.v10n5p89

URL: https://doi.org/10.5430/rwe.v10n5p89

\begin{abstract}
The purpose of this paper is to determine the implementation of total productive maintenance in Malaysian automotive industry. 400 questionnaires were distributed to Malaysian automotive industry and 229 were completed, giving a response rate of $57.25 \%$. Based on the developed models, the results of the study provide guidance for effective implementation of total productive maintenance in Malaysian automotive industry. This study makes a new contribution to the Malaysian automotive industry for total productive maintenance implementation. This study provides important information for decision makers to implement total productive maintenance in automotive industry and also provides useful information for future researchers in the total productive maintenance area.
\end{abstract}

Keywords: total productive maintenance, quality, innovation, automotive industry

\section{Introduction}

The automotive industry contributes to the economy which is related to manufacturing sectors. Malaysian automotive industry is one of the important sectors that focus on the operations and components of the automotive (Habidin, Zubir, Conding, Jaya, \& Hashim, 2013). Like quality, maintenance is an issue of strategic importance (Tambe \& Kulkarni, 2016). Total Productive Maintenance (TPM) is one of the quality engineering approaches for improving maintenance effectiveness. Maintenance directly affected the efficiency and effectiveness in the manufacturing organization (Singh \& Ahuja, 2014; Soner, Gul \& Yildirim, 2016). TPM as one of the quality approach, such as total quality management, just-in-time, and continuous improvement (Bartz, Siluk, \& Bartz, 2014; Jamkhaneh, Pool, Khaksar, Arabzad, \& Kazemi, 2018). This approach can improve the performance, new technology, research, operations, and manufacturing process.

TPM is a practice that support lean manufacturing systems. It also supports the practices under lean umbrella such as, Just in Time, Total Quality Management and TPM. It is important in the evolution of world manufacturing for giving a new evolution in maintenance system and product quality (Jain, Singh, \& Bhatti, 2018). TPM provide a new view on the maintenance especially on the quality of the organization (Rukijkanpanich \& Pasuk, 2018). TPM also can assist the organization for improving quality, operations, productivity, and safety, particularly in the Malaysian automotive industry (Bilan et al., 2019).

In 1971 the Japanese introduced and developed the concept of TPM, regarding to the maintenance and solve problems in the manufacturing industry (Ighravwe \& Oke, 2017a). For example, TPM focused on the production and maintenance, continuous improvement, quality, efficiency, capacity, assurance, and safety (Habidin \& Yusof, 2013; Ighravwe \& Oke, 2017b; Chankoson, 2019). The maintenance is an essential in the automotive industry and it provides for productivity.

Furthermore, TPM approach use the term "you operate, I maintain" because it shows the maintenance implementation in TPM practices involve cooperation between subordinates and superiors. It also involves all parties 
in the continuous improvement of performance (Gandhare, Akarte, \& Patil, 2018). TPM concerned with the work as a team to eliminate the problem causes. Teamwork is through small group activities designed to zero in terms of breakdown and defect. The three elements of teamwork are:

i) To maximize effectiveness of the equipment

ii) Handling ongoing maintenance

iii) To improve the maintenance activities, throughout the entire organization

TPM is known as the "high-employee involvement" approach. It can have an impact on employees' minds to be more creative and more motivated. Generally, TPM starts from the top direction, implemented by the bottom, and was succeeded by the top management. It requires a high commitment from all employees facilitate this implementation (Velmurugan \& Dhingra, 2015; Habidin, Hashim, Fuzi, \& Salleh, 2018; Sahoo, 2018). Moreover, TPM is a manufacturing practice that emphasizes their actions and attitudes of employees to make improvement in maintenance. The manufacturer and maintenance employees also need to work together. In essence, TPM also use the individual potential in extensively to improve the productivity.

TPM is beneficial to reduce the damage and can assist in the improvement activities (Phogat \& Gupta, 2017; Gopalakrishnan \& Skoogh, 2018; Tsarouhas, 2019). Hence, TPM assist in terms of maintenance schedule compilation and small tasks maintenance. The author added that the TPM is a cultural practice, philosophy, and new attitude in maintenance.

Thus, to support the statement above, TPM is beyond the traditional maintenance system which not only intends to avoid damage, but also to make full use of the equipment life (Makinde, Mpofu, \& Ramatsetse, 2016; Bosupeng, 2018). The use of TPM in the manufacturing industry discovered that TPM practices are needed to maximize the use of equipment and reduce maintenance costs. It is a way to ensure the equipment is maintained in optimum circumstances in order to deal with unexpected damage, wastage of time and quality in processing. It promotes productive maintenance which involves all employees from the lower level to the top level management.

The next benefit of implementing TPM practices is to improve productivity and quality. For the automotive industry, the end product is of paramount importance as it reflects organizational performance. Accordingly, a study done by Ding, Kamaruddin, and Azid (2014) has identified that the TPM practice is a factor to increase the productivity and quality of the organization. TPM is a practice which is carried out diligently as they impact the maximum as a dramatic increase in productivity (Koussaimi, Bouami, \& Elfezazi, 2016). It seeks to minimize and maximize output through the better quality output with lower cost.

Next, the dimensions are Autonomous Maintenance (AM), Planned Maintenance (PM), Quality Maintenance (QM), and Education and Training (ET). Based on that, Majumdar and Manohar (2012) stated that AM has six elements, cleaning, causes and effects of maintenance, inspection, maintenance, tidiness, and full maintenance implementation. This element creates company culture in the maintenance activities. Based on AM, it can provide to the continuous improvement in terms of follow-up activities to improve the maintenance and quality (Shafeek, 2014; Ylipää, Bokrantz, \& Gopalakrishnan, 2017; Wonyra, 2018). Further, AM also involves the management. By implementing AM, it can reduce breakdown, to preventative and corrective maintenance in AM to the organization, particularly in Malaysian automotive industry.

The goal of PM is to improve machines and equipment for defect-free products. PM can improve and sustains conditions of machines at optimum cost of maintenance, reduces inventory, and enhance reliability and maintainability (Gerdes, Scholz, \& Galar, 2016; Fengyang, 2018). PM from a reactive approach to a proactive approach from the maintenance to maintain the equipment. There are four types of PM:

i. preventive maintenance; and

ii. maintenance prevention.

QM activities are to produce zero defects and to reduce damage in order to improve product quality and to fulfill customer satisfaction. QM activities include equipment conditions based on the maintenance of equipment (Jain, Bhatti, \& Singh, 2015). Some of the QM activities are based on the conditions to reduce damage, to improve product quality, and increase the equipment conditions. According to Hooi and Leong (2017), QM can improve customer requirement through quality equipment. QM can be accomplished as follows:

i. Improving an equipment conditions which is to eliminate damage products

ii. Becoming proficient in equipment from managers to operators. 
a. Elimination of forced deterioration.

b. To improve the employees' skills in the operations and maintenance.

c. Equipment zero failures.

d. Maintenance prevention design of new products and new equipment.

ET is needed in management as workers are not capable of performing assigned tasks well. Employees need to add to their talents and knowledge to get job satisfaction. Generally, employees only maintain equipment without knowing the reason and cause damage. This element can assist the employees directly (Wakjira \& Singh, 2012). As such, ET is needed in the TPM practices. With ET, employees are able to improve the management of equipment and machinery which need to understand the problems and be able to solve the problems. Therefore, this study is focused on the four dimensions of TPM such as autonomous maintenance, planned maintenance, quality maintenance, and education and training.

\section{Methodology}

Data for the study were collected from 229 companies of Malaysian automotive industries. By using survey methods, it can clarify the survey respondents to be used as collected data for analysis (Habidin, Fuzi, Desa, Hibadullah, \& Zamri, 2014). 400 questionnaires were distributed to Malaysian automotive industry and 229 were completed, giving a response rate of $57.25 \%$. In obtaining expert validation, the final draft of the questionnaire was sent to TPM experts in industry as well as academicians. Comment and feedback given were used for improving of the instrument to gain content validity.

First, Exploratory Factor Analysis (EFA) was used to identify the TPM items and to suggest items for deletion (Wiktorowicz, 2017; Wonyra, 2018). Conducting EFA indicated whether all items within the scale loading on the same construct or whether the summated scale measures more than one construct. In this study, EFA was conducted on TPM dimensions. Convergent validity was tested for each dimension, thus item loading more than 0.4 was accepted (Dubey, Singh, Ali, Venkatesh, \& Gupta, 2014; Habidin, Yusof, \& Fuzi, 2016; Jandali \& Sweis, 2018). The second was the confirmation on developed factors or constructs. In this study, the Confirmatory Factor Analysis (CFA) was conducted based on the multiple factor first order confirmatory. CFA is the most comprehensive method to test and examine how well the data set fits the measurement (Chawla \& Saxena, 2016; Farooq, 2016).

\section{Results}

The total number of valid respondents is 229 from Malaysian automotive industry. Exploratory Factor Analysis (EFA) with varimax rotation shown on TPM dimensions. 0.4 factor loading of each item are considered as acceptable values (Fuzi, Habidin, Hibadullah, \& Ong, 2017). Kaiser-Meyer-Olkin (KMO) results was 0.946 which is more than 0.7, indicated that it was suitable for principal component analysis. The EFA of 20 items for TPM was $66.877 \%$ of the total variance. The result presented that TPM had identified four dimensions (AM, PM, QM, and ET) with 20 items. Table 1 shows the KMO and Bartlett's test for TPM.

Table 1. KMO and Bartlett's test for TPM

\begin{tabular}{lcc}
\hline Kaiser-Meyer-Olkin Measure of Sampling Adequacy. & 0.946 \\
& Approx. Chi-Square & 2714.621 \\
Bartlett's Test of Sphericity & Df & 190 \\
& Sig. & 0.000 \\
Total Variance Explained & & $66.877 \%$
\end{tabular}

Other than that, the Cronbach's alpha of TPM dimensions ranged from 0.760 to 0.920 . According to Nunnally (1978) and Niknam and Sawhney (2014), the acceptable alpha value was 0.6 for exploratory work. It showed that the use of good scales for reliability analysis. Cronbach's Alpha value for each factor was more than 0.70 , thus all the identified factors were accepted for this study (Sinha, 2015; Fuzi, Habidin, Hibadullah, Zamri, \& Desa, 2015). Table 2 shows the reliability analysis of TPM dimensions. 
Table 2. Reliability analysis of TPM dimensions

\begin{tabular}{lcccc}
\hline Dimensions & $\begin{array}{c}\text { No. of } \\
\text { items }\end{array}$ & $\begin{array}{c}\text { Alpha }(\alpha) \\
\text { values }\end{array}$ & $\begin{array}{c}\text { Item for } \\
\text { deletion }\end{array}$ & $\begin{array}{c}\text { Alpha }(\alpha) \text { if item is } \\
\text { deleted }\end{array}$ \\
\hline TPM & & & & \\
Autonomous Maintenance (AM) & 5 & 0.864 & None & 0.864 \\
Planned Maintenance (PM) & 5 & 0.898 & None & 0.898 \\
Quality Maintenance (QM) & 5 & 0.760 & None & 0.760 \\
Education and Training (ET) & 5 & 0.920 & None & 0.920 \\
\hline
\end{tabular}

The next analysis involves Confirmatory Factor Analysis (CFA) testing the measurement model of TPM dimensions. The model demonstrated that TPM implementation including AM, PM, QM, and ET. TPM model with four dimensions showed acceptable results. $\chi 2$ statistics was 205.822 (degree of freedom $=164, p<0.001$ ), with ratio of $\chi 2$ df value being 1.255 less than 2.0 thus exhibiting a good fit. Goodness Fit Index (GFI) was 0.919 and Adjusted Goodness of Fit (AGFI) was 0.897 which was moderate fit. The comparative fit index (CFI) was 0.984, Tucker Lewis coefficient (TLI) was 0.981. The value of (RMSEA) was 0.033 less than 0.08; thus the results showed a good fit. All canonical correlation (rc) showed values less than 1.0 and discriminant validity was acceptable for this study (see Figure 1). Therefore, it is suggested that these four dimensions as applicable for effective of TPM implementation in Malaysian automotive industry.

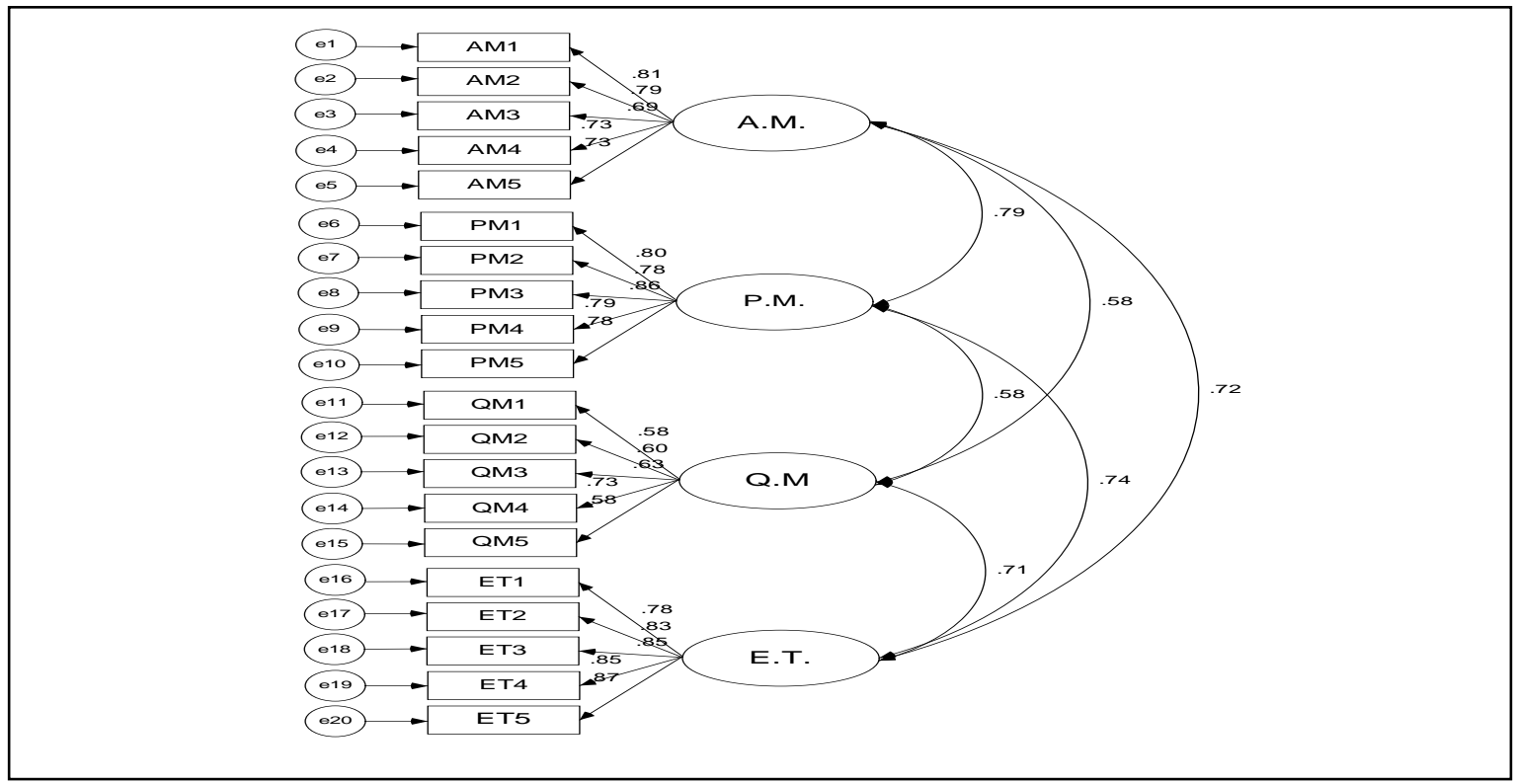

Figure 1. The output path diagram for TPM model

\section{Discussion}

The result of analysis showed that the four dimensions used in this study are acceptable. This four factors, namely AM, PM, QM, and ET show the results that indicate such interdependencies and contribute to the successful implementation of TPM practices. It also corroborates with results of previous studies that examined TPM practices in various countries such as the one by Rolfsen (2014) who identified that AM could discipline the maintenance planning tasks, information and schedule to increase the effective of TPM implementation. This study also suggested that AM is related to housekeeping, cross training and operator involvement. A study done by Shafiee (2015) showed that the organization had followed seven steps of AM such as employees, clean-up of machines, take counter measures, fix AM standards, inspection, autonomous inspection, and standardization. The organizations have been using the AM but at different levels according to their organizational ability. According Macchi and Fumagalli (2013), employee training is one of the effective for TPM implementation. This is due to provide a good employee training and also can assist the employees to understand the effective of TPM implementation. Regarding to this, the organization can improve the TPM implementation and performance for Malaysian automotive industry.

From the findings, the results of four dimensions showed that the measurement model for TPM (AM, PM, QM, and 
ET) had a good fit and is valid and reliable for Malaysian automotive industry. In terms of academic and practical contribution, this study has focused on developing a model of TPM based on factors which have been set. It can increase the literacy and assists researchers in understanding these practices. Moreover, it also provides guidelines and references for research in the future. There are several key contributions in this study as contribution in validated items. By using the structural equation modelling technique, four TPM dimensions were identified. This study had shown that empirical test results prove that the implementation of TPM in Malaysian automotive industry were acceptable. The outcome of this study can also provide guidelines for managers and practitioners of automotive industry for effective total productive maintenance implementation. Therefore, this study can assist the managers and employees and also give a new perspective to the practice of TPM. Based on the developed models, the results of the study also provide guidance on the implementation and recommendations to the Malaysian automotive industry.

Meanwhile, the limitation in this research is the number of factors and limited measurement in this study. Only a few TPM factors were considered. There are other factors which are appropriate in implementing TPM in the automotive industry. Other factors in TPM practices are leadership factor, total cost, government support, and culture. These factors can be considered in future studies. However, the view of TPM practices is still new in Malaysia and not fully implemented because some factors are not suitable to be investigated for this study.

Furthermore, the researcher was unable to obtain the feedback from consultants in TPM to verify the instrument which had been used. However, this instrument had been validated by industry experts and academic experts in this field. The instrument validation was important to ensure that the objectives of this study could be achieved. The future agenda for this research is the author interested to study about the relationship between TPM and kaizen event has an impact on the innovation performance in Malaysian automotive industry. Next, it could be suggested that future studies to improve the TPM implementation through the variables between quantitative and qualitative study to obtain much better elements relevant for the current issues in the automotive industry. The green and sustainable element is very appropriate to combine with TPM practices and to improve the performance, particularly in Malaysian automotive industry.

\section{Acknowledgements}

The researchers would like to acknowledge Ministry of Education Malaysia for the financial funding of this research through Prototype Research Grant Scheme (PRGS, 2012-0090-106-32) (PRGS/1/2012/SS05/UPSI/03/1) and Research Management and Innovation Centre (RMIC), Universiti Pendidikan Sultan Idris (UPSI).

\section{References}

Bartz, T., Siluk, J.C.M., \& Bartz, A.P.B. (2014). Improvement of industrial performance with TPM implementation. Journal of Quality in Maintenance Engineering, 20(1), 2-19.

Bilan, Y., Rubanov, P., Vasylieva, T., \& Lyeonov, S. (2019). The influence of industry 4.0 on financial services: Determinants of alternative finance development. Polish Journal of Management Studies, 19(1), 70-93.

Bosupeng, M. (2018). Leading Indicators and Financial Crisis: A Multi-Sectoral Approach Using Signal Extraction. Journal of Empirical Studies, 5(1), 20-44.

Chawla, A., \& Saxena, S. (2016). A confirmatory factor analysis of knowledge management assessment instrument in Indian higher educational institutions. International Journal of Quality \& Reliability Management, 33(7), 1019-1029.

Chankoson, T. (2019). Multilevel causal factors affecting the strategic success of Thai export businesses. Polish Journal of Management Studies, 19(1), 94-105.

Ding, S., Kamaruddin, S., \& Azid, I.A. (2014). Maintenance policy selection model - a case study in the palm oil industry. Journal of Manufacturing Technology Management, 25(3), 415-435.

Dubey, R., Singh, T., Ali, S.S., Venkatesh, V.G., \& Gupta, O.K. (2014). Exploring dimensions of firm competencies and their impact on performance: Some exploratory empirical results. Benchmarking: An International Journal, 21(6), 1003-1022.

Farooq, R. (2016). Role of structural equation modeling in scale development. Journal of Advances in Management Research, 13(1), 75-91.

Fengyang, W.U. (2018). An Analysis of Chinas Poverty Research Based on CiteSpace. Journal of Social Economics Research, 5(2), 75-84.

Fuzi, N.M., Habidin, N.F., Hibadullah, S.N., \& Ong, S.Y.Y. (2017). CSR practices, ISO 26000 and performance among Malaysian automotive suppliers. Social Responsibility Journal, 13(1), 203-220.

Fuzi, N.M., Habidin, N.F., Hibadullah, S.N., Zamri, F.I.M., \& Desa, A.F.N.C. (2015). Critical success factors of corporate social responsibility practices for the Malaysian automotive industry. International Journal of Critical 
Accounting, 7(2), 142-156.

Gandhare, B.S., Akarte, M.M., \& Patil, P.P. (2018). Maintenance performance measurement - a case of the sugar industry. Journal of Quality in Maintenance Engineering, 24(1), 79-100.

Gerdes, M., Scholz, D., \& Galar, D. (2016). Effects of condition-based maintenance on costs caused by unscheduled maintenance of aircraft. Journal of Quality in Maintenance Engineering, 22(4), 394-417.

Gopalakrishnan, M., \& Skoogh, A. (2018). Machine criticality based maintenance prioritization: Identifying productivity improvement potential. International Journal of Productivity and Performance Management, 67(4), 654-672.

Habidin, N.F., \& Yusof, S.M. (2013). Critical success factors of lean six sigma for Malaysian automotive industry. International Journal of Lean Six Sigma, 4(1), 60-82.

Habidin, N.F., Fuzi, N.M., Desa, A.F.N.C., Hibadullah, S.N., \& Zamri, F.I.M. (2014). ISO 26000 efforts and corporate social responsibility performance in Malaysian automotive industry. International Journal of Business Excellence, 7(4), 515-529.

Habidin, N.F., Hashim, S., Fuzi, N.M., \& Salleh, M.I. (2018). Total productive maintenance, kaizen event, and performance. International Journal of Quality \& Reliability Management, 35(9), 1853-1867.

Habidin, N.F., Yusof, S.M., \& Fuzi, N.M. (2016). Lean six sigma, strategic control systems, and organizational performance for automotive suppliers. International Journal of Lean Six Sigma, 7(2), 110-135.

Habidin, N.F., Zubir, A.F.M., Conding, J., Jaya, N.A.S.L., \& Hashim, S. (2013). Sustainable manufacturing practices, sustaining lean improvement and sustainable performance in Malaysian automotive industry. World Review of Entrepreneurship, Management and Sustainable Development, 9(4), 444-459.

Hooi, L.W., \& Leong, T.Y. (2017). Total productive maintenance and manufacturing performance improvement. Journal of Quality in Maintenance Engineering, 23(1), 2-21.

Ighravwe, D.E., \& Oke, S.A. (2017a). Ranking maintenance strategies for sustainable maintenance plan in manufacturing systems using fuzzy axiomatic design principle and fuzzy-TOPSIS. Journal of Manufacturing Technology Management, 28(7), 961-992.

Ighravwe, D.E., \& Oke, S.A. (2017b). Sustenance of zero-loss on production lines using Kobetsu Kaizen pillar of TPM with hybrid model. Total Quality Management \& Business Excellence, 1-25.

Jain, A., Bhatti, R.S., \& Singh, H. (2015). OEE enhancement in SMEs through mobile maintenance: A TPM concept. International Journal of Quality \& Reliability Management, 32(5), 503-516.

Jain, A., Bhatti, R., \& Singh, H. (2014). Total productive maintenance (TPM) implementation practice: A literature review and directions. International Journal of Lean Six Sigma, 5(3), 293-323.

Jain, A., Singh, H., \& Bhatti, R.S. (2018). Identification of key enablers for total productive maintenance (TPM) implementation in Indian SMEs: A graph theoretic approach. Benchmarking: An International Journal, 25(8), 2611-2634.

Jamkhaneh, H.B., Pool, J.K., Khaksar, S.M.S., Arabzad, S.M., \& Kazemi, R.V. (2018). Impacts of computerized maintenance management system and relevant supportive organizational factors on total productive maintenance. Benchmarking: An International Journal, 25(7), 2230-2247.

Jandali, D., \& Sweis, R. (2018). Assessment of factors affecting maintenance management of hospital buildings in Jordan. Journal of Quality in Maintenance Engineering, 24(1), 37-60.

Koussaimi, M.A., Bouami, D., \& Elfezazi, S. (2016). Improvement maintenance implementation based on downtime analysis approach. Journal of Quality in Maintenance Engineering, 22(4), 378-393.

Macchi, M., \& Fumagalli, L. (2013). A maintenance maturity assessment method for the manufacturing industry. Journal of Quality in Maintenance Engineering, 19(3), 295-315.

Majumdar, J.P., \& Manohar, B.M. (2012). Implementing TPM programme as a TQM tool in Indian manufacturing industries. Asian Journal on Quality, 13(2), 185-198.

Makinde, O.A., Mpofu, K., \& Ramatsetse, B. (2016). Establishment of the best maintenance practices for optimal reconfigurable vibrating screen management using decision techniques. International Journal of Quality \& Reliability Management, 33(8), 1239-1267.

Modgil, S., \& Sharma, S. (2016). Total productive maintenance, total quality management and operational performance: An empirical study of Indian pharmaceutical industry. Journal of Quality in Maintenance Engineering, 22(4), 353-377. 
Niknam, S.A., \& Sawhney, R. (2014). A model for reliability analysis of multi-state manufacturing systems. International Journal of Quality \& Reliability Management, 31(8), 938-949.

Nunnally, J.D. (1978). Psychometric theory. McGraw-Hill, New York.

Phogat, S., \& Gupta, A.K. (2017). Identification of problems in maintenance operations and comparison with manufacturing operations: A review. Journal of Quality in Maintenance Engineering, 23(2), 226-238.

Piechnicki, A.S., Sola, A.V. H., \& Trojan, F. (2015). Decision making towards achieving world-class total productive maintenance. International Journal of Operations \& Production Management, 35(12), 1594-1621.

Rolfsen, M. (2014). A blueprint paradox: Successful but unintended cross-national translation of total productive maintenance. Journal of Quality in Maintenance Engineering, 20(4), 402-414.

Rukijkanpanich, J., \& Pasuk, P. (2018). Maintenance management for transportation process in quarry industry. Journal of Quality in Maintenance Engineering, 24(2), 185-199.

Sahoo, S. (2018). An empirical exploration of TQM, TPM and their integration from Indian manufacturing industry. Journal of Manufacturing Technology Management, 29(7), 1188-1210.

Salleh, N.A.M., Kasolang, S., \& Jaafar, A. (2012). Review study of developing an integrated TQM with LM framework model in Malaysian automotive industry. The TQM Journal, 24(5), 399-417.

Shafeek, H. (2014). Continuous improvement of maintenance process for the cement industry - a case study. Journal of Quality in Maintenance Engineering, 20(4), 333-376.

Shafiee, M. (2015). Maintenance strategy selection problem: An MCDM overview. Journal of Quality in Maintenance Engineering, 21(4), 378-402.

Singh, K., \& Ahuja, I.S. (2014). Effectiveness of TPM implementation with and without integration with TQM in Indian manufacturing industries. Journal of Quality in Maintenance Engineering, 20(4), 415-435.

Singh, K., \& Ahuja, I.S. (2015). An evaluation of transfusion of TQM-TPM implementation initiative in an Indian manufacturing industry. Journal of Quality in Maintenance Engineering, 21(2), 134-153.

Sinha, P. (2015). Towards higher maintenance effectiveness: integrating maintenance management with reliability engineering. International Journal of Quality \& Reliability Management, 32(7), 754-762.

Soner, A.K.I.N., Gul, Z., \& Yildirim, U. (2016). A Theoretical Analysis Upon the Environmental Health and Justice Issue: A Case Study for a Comparison Between G20s Unitary and Federal Members. International Journal of Sustainable Development \& World Policy, 5(2), 26-38.

Tambe, P.P., \& Kulkarni, M.S. (2016). Selective maintenance optimization under schedule and quality constraints. International Journal of Quality \& Reliability Management, 33(7), 1030-1059.

Tsarouhas, P. (2019). Improving operation of the croissant production line through overall equipment effectiveness (OEE): A case study. International Journal of Productivity and Performance Management, 68(1), 88-108.

Velmurugan, R.S., \& Dhingra, T. (2015). Maintenance strategy selection and its impact in maintenance function: A conceptual framework. International Journal of Operations \& Production Management, 35(12), 1622-1661.

Wakjira, M.W., \& Singh A.P. (2012). Total productive maintenance: A case study in manufacturing industry. Global Journal of Researches in Engineering Industrial Engineering, 12(1), 24-32.

Wickramasinghe, G.L.D., \& Perera, A. (2016). Effect of total productive maintenance practices on manufacturing performance: Investigation of textile and apparel manufacturing firms. Journal of Manufacturing Technology Management, 27(5), 713-729.

Wiktorowicz, J. (2017). Competencies as a factor of economic deactivation: Application of exploratory factor analysis. International Journal of Social Economics, 44(5), 605-619.

Wonyra, K.O. (2018). Impact of Telecommunications Market Liberalization on Labor Productivity in Economic Community of West African States. Journal of Social Economics Research, 5(2), 63-74.

Wonyra, K.O. (2018). Industrialization and Economic Growth in Sub-Saharan Africa: The Role of Human Capital in Structural Transformation. Journal of Empirical Studies, 5(1), 45-54.

Ylipää, T., Skoogh, A., Bokrantz, J., \& Gopalakrishnan, M. (2017). Identification of maintenance improvement potential using OEE assessment. International Journal of Productivity and Performance Management, 66(1), 126-143.

Zulkifli, M., \& Saripuddin, O.A.S.S. (2015). Concept of business ethics in Islam-approach to the entrepreneur. Journal of Asian Business Strategy, 5(1), 13-18. 